\title{
Identification of an alternative splicing transcript for the resistin gene and distribution of its mRNA in human tissue
}

Tomoyoshi Nohira, Kumi Nagao ${ }^{1}$, Kazuhisa Kameyama ${ }^{3}$, Hiromi Nakai, Noritaka Fukumine, Kazuhiro Okabe, Soichi Kitano ${ }^{2}$ and Hisashi Hisatomi ${ }^{2}$

Department of Obstetrics and Gynecology, Hachioji Medical Center of Tokyo Medical University, Tokyo 193-0998, Japan, ${ }^{1}$ Center for Molecular Biology and Cytogenetics and ${ }^{2}$ Analytical Center for Medical Science, SRL, Inc., 153 Komiya-machi Hino, Tokyo 192-OO31, Japan and ${ }^{3}$ LifeScience Division, Nihon Millipore K.K., 1-4-28 Mita, Minato-ku, Tokyo 108-0073, Japan

(Correspondence should be addressed to H Hisatomi; Email: hisatomi@srl.srl-inc.co.jp)

\begin{abstract}
Objective: Adipocytes secrete a number of molecules such as tumor necrosis factor-alpha, leptin and free fatty acids that can influence the ability of the body to metabolize glucose. Recently, a novel $12.5 \mathrm{kDa}$ cysteine-rich protein, termed resistin, was shown to be secreted by adipocytes. Resistin expression was markedly induced during the conversion of 3T3-L1 cells to mature adipocytes. Expression of resistin has been studied in human, mouse and rat; however, sequence information about an alternative splicing variant (ASV) of resistin mRNA has not been reported. In the present study, we investigated the occurrence of a novel ASV of the resistin gene in human normal tissues. Design and methods: We identified a novel ASV of resistin mRNA in human lung tissue by RT-PCR analysis in human lung tissue. We then investigated a novel ASV of resistin mRNA by real-time PCR analysis in 26 different types of normal human tissues.

Results and conclusions: We identified a novel deletion variant of the resistin transcript in the normal human tissues. The deleted transcript of resistin was characterized by an in-frame deletion of $78 \mathrm{bp}$, corresponding to the complete loss of exon 2 (resistin delta2 ASV). Thus, resistin delta2 ASV causes protein truncation. Our results provide the basis for more detailed studies on the regulation of resistin activity, and should assist in the development of clinical trials with resistin for the central regulation of adipogenesis and adipocyte metabolism.
\end{abstract}

European Journal of Endocrinology 151 151-154

\section{Introduction}

Adipose tissue is the body's largest endocrine organ producing hormones, cytokines and other proteins such as leptin, tumor necrosis factor-alpha and interleukin-6. Resistin is a recently described peptide hormone secreted by adipocytes, and belongs to a novel class of cysteine-rich secreted proteins termed the resistin-like molecule/found in inflammatory zone (RELM/FIZZ) family (1-3). Resistin is secreted by 3T3-L1 cells, and the gene expression is attenuated (4) by potent sensitizers of insulin action; it is a potential link between obesity and insulin resistance by virtue of its production by adipose tissue (5).

Resistin is generally not detectable or is only expressed at extremely low levels with sensitive realtime PCR in human muscle, fat cells, brain and pituitary (6-8). The human resistin (hResistin) gene was mapped in the p13.3 of the short arm of chromosome 19 , spans over $1.3 \mathrm{~kb}$ and consists of three exons separated by intronic sequences (4). The complete cDNA sequence determined as a full-length resistin encoding a 108 amino acid polypeptide. Expression of resistin has been studied in human, mouse and rat (4-13); however, sequence information about an alternative splicing variant (ASV) of resistin mRNA has not been reported. Alternative splicing of the primary transcript is a fundamental biological process involved in the expression of genes; general alternative splicing can produce variant proteins and expression patterns as different as are the products of different genes (14-19). In the present study, we investigated the occurrence of a novel ASV of the resistin gene in human normal tissues.

\section{Materials and methods}

\section{ASV identification}

To identify a novel ASV of the hResistin gene, extracted total RNA from normal lung tissue was purchased (CLONTECH, Palo Alto, CA, USA). cDNA was prepared by incubating DNase-treated total RNA (1.0 $\mu \mathrm{g})$ with M-MLV reverse transcriptase (Invitrogen, San Diego, 
CA, USA) in the presence of random primers (Invitrogen). The primer set for amplification of a resistin mRNA was designed according to GenBank AF323081, using forward primers at the exon 1 region: 5'-TGG AAG AAG CCA TCA ATG AGA GG-3', and reverse primers at the exon 3 region: $5^{\prime}$-CGC ACT GGC AGT GAC ATG TG-3'. Reaction parameters were $95^{\circ} \mathrm{C}$ for $30 \mathrm{~s}, 60{ }^{\circ} \mathrm{C}$ for $40 \mathrm{~s}$, and $72{ }^{\circ} \mathrm{C}$ for $30 \mathrm{~s}$ for 45 cycles, followed by a $10 \mathrm{~min}$ extension at $72^{\circ} \mathrm{C}$ using AmpliTaq Gold DNA polymerase (PE Applied Biosystems, Foster, CA, USA). Half of the PCR product was separated using electrophoresis in TBE buffer on $3.0 \%$ agarose gel, stained with ethidium bromide, and then detected with u.v. light (Fig. 1). The PCR products of resistin were purified using a High Pure PCR Product Purification Kit (Roche Molecular Biochemicals Diagnostics, Indianapolis, IN, USA), cloned into a pCR2.1 vector (Invitrogen), and then sequenced using a BigDye Terminator Cycle Sequencing Ready Reaction Kit (PE Applied Biosystems) with an ABI PRISM 3100 Genetic Analyzer (PE Applied Biosystems). Finally, the sequence was compared with a full-length resistin mRNA sequence.

\section{Full-length mRNA and resistin delta2 ASV in human tissues}

Extracted total RNA, 26 different types of Human Total RNA, from normal samples were purchased (CLONTECH): adrenal gland, adipose, bone marrow, breast, cerebellum, whole brain, colon, fetal brain, fetal liver, heart, kidney, liver, lung, ovary, pancreas, peripheral blood, placenta, prostate, skeletal muscle, small intestine, spleen, stomach, testis, thymus, thyroid gland and uterus. cDNA was synthesized with a random primer using $1.0 \mu \mathrm{g}$ each of Human Total RNA.

The real-time PCR reaction mixture was prepared using a TaqMan PCR Core Reagents Kit (PE Applied Biosystems). The primers to amplify mRNA for the full-length isoform were designed as a forward primer at exons 1-2: 5'-CGC CGG CTC CCT AAT ATT TA-3', and reverse primer at exon 3: 5'-GCT GCA CAC GAC AGC AGC G-3' (218 bp). The primer set for amplification of resistin delta 2 ASV, lacking entirely exon 2, mRNA was detected using the forward primer at the bridged exons 1 and 3 junction region: 5'-CGC CGG CTC CCT

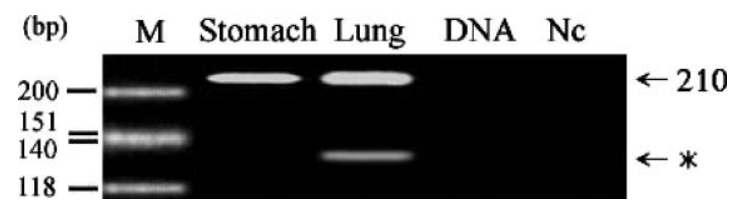

Figure 1 Alternative splicing of hResistin mRNA. Stomach, human stomach cDNA; Lung, human lung cDNA; DNA, genomic DNA; Nc, negative control (RNase free water); $\mathrm{M}$, molecular weight marker $\varnothing X 174$ DNA/Hinfl digest. Size indications (number of base pairs), are shown. An obviously shorter signal (* arrow) is observed in the lung sample.
AAG CTT C-3', and the reverse primer at the exon 3 region: 5'-GCT GCA CAC GAC AGC AGC G-3' (140 bp). The common probe between the full-length isoform and the ASV (5'-CGC GCC GAG ACC ACA TGT CAC TGC- $\left.3^{\prime}\right)$ was designed at the exon 3 region.

The real-time PCR reaction was carried out at 50 cycles $\left(95^{\circ} \mathrm{C}\right.$ for $30 \mathrm{~s}, 60^{\circ} \mathrm{C}$ for $40 \mathrm{~s}$, and $72^{\circ} \mathrm{C}$ for $30 \mathrm{~s}$ ) using a real-time PCR system (ABI PRISM 7700 Sequence Detection System: PE Applied Biosystems). The PCR products of the full-length isoform of the hResistin gene and the hResistin delta2 ASV were directly sequenced, and this was then compared with a target mRNA sequence.

\section{Results}

\section{ASV identification}

The PCR mixture presented two bands on electrophoresis (Fig. 1); the sizes of these PCR products being $210 \mathrm{bp}$ (full-length isoform) and $132 \mathrm{bp}$. The sequence of the $132 \mathrm{bp}$ product lacked $78 \mathrm{bp}$ from the entire exon 2 (resistin delta2) (Fig. 2). The protein encoded by the resistin delta 2 ASV mRNA is 26 amino acids shorter than the full-length isoform. No frameshift mutation was observed, thus the amino acid sequences without the missing region were conserved. The possibility that the deleted transcripts could have resulted from PCR false priming or other artifacts was excluded, since triplicate experiments based on independent RNA extractions and cDNA preparations yielded consistent results. Thus, we have identified a novel ASV. These sequences were compared with non-redundant sequences in GenBank; no identical sequences were found. The sequence of resistin delta2 was submitted to GenBank, access number AB111910.

\section{ASV expression in human tissues}

The full-length of the hResistin mRNA was detected by RT-PCR analysis in adrenal gland, adipose, bone marrow, breast, whole brain, colon, fetal brain, fetal

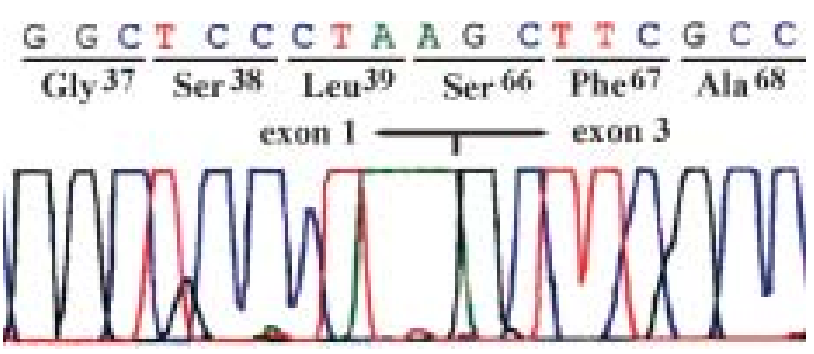

Figure 2 Sequence analysis of the transcript bearing the deletion of exon 2 of the hResistin gene. The sequence shows the in-frame deletion, corresponding to the complete loss of exon 2. Because no frameshift mutation is observed, amino acids sequences without the missing region are conserved. A glycine (Gly) to serine (Ser) transition is revealed at codon 66. 
liver, heart, kidney, liver, lung, pancreas, peripheral blood, placenta, prostate, skeletal muscle, small intestine, spleen, stomach, testis, thymus, thyroid gland and uterus (Fig. 3). The full-length of the hResistin mRNA was not detected in cerebellum and ovary (Fig. 3). The hResistin delta 2 mRNA was detected by real-time RT-PCR analysis in adipose, bone marrow, whole brain, fetal brain, fetal liver, lung, peripheral blood, placenta and thymus (Fig. 3).

Real-time RT-PCR analysis of hResistin delta2 mRNA in multiple human tissues showed that the transcript was expressed at very high levels in bone marrow and lung (Fig. 3). The content of hResistin delta 2 mRNA in bone marrow was about twofold higher than in lung, the tissue with the next highest expression.

\section{Discussion}

We demonstrated the existence in several normal human tissues of a novel alternatively spliced hResistin transcript characterized by the deletion of exon 2 (hResistin delta2). Alternative splicing is a common gene control mechanism, and up to a third of human genes are alternatively spliced (18), and several ASVs have been associated with human diseases $(17-21)$. The hResistin delta2 transcript conserves only 82 amino acids $(75.9 \%)$ of full-length isoform, which has a peptide of 108 amino acids; thus, hResistin delta2 ASV will result in a partial defect. Having hResistin delta2 ASV causes no premature translation termination, suggesting that it may be a candidate as a dominantnegative inhibitor of resistin. Usually, most mRNAs resulting in protein truncation, including the hResistin ASVs, may be efficiently degraded by a pathway known as nonsense-mediated mRNA decay (NMD) $(22,23)$. Because $h$ Resistin ASV mRNA avoided involvement in a NMD mechanism, this ASV may have some effective roles. In our preliminary study, the deleted exon 2 variant also existed in mouse and rat tissues (data not shown). Further improved studies are needed to clarify the mechanisms involved in this phenomenon.

Human resistin protein expression was detected in gonadal white adipose tissue, perirenal white adipose tissue, brain and pituitary (8); it was not observed in heart, spleen, lung, liver, kidney, testis, colon, small intestine, tongue and brown adipose tissue $(4,24$, $25)$. However, mRNA expression was detected in multiple tissues in this study. Our result complements that of Patel et al. (12) who reported that resistin mRNA was detected in normal lung, kidney, spleen, placenta and bone marrow. Since the RNA (especially muscle, heart and colon) purchased from CLONTECH might be contaminated with adipose tissue, further studies in a larger number of samples are required to confirm these results. There are still concerns that the mechanism of resistin protein translation from mRNA may be regulated by unknown factors.

The expression of ASV that induced the mimic resistin transcript needs to be considered when designing strategies for regulation analysis of the resistin gene.

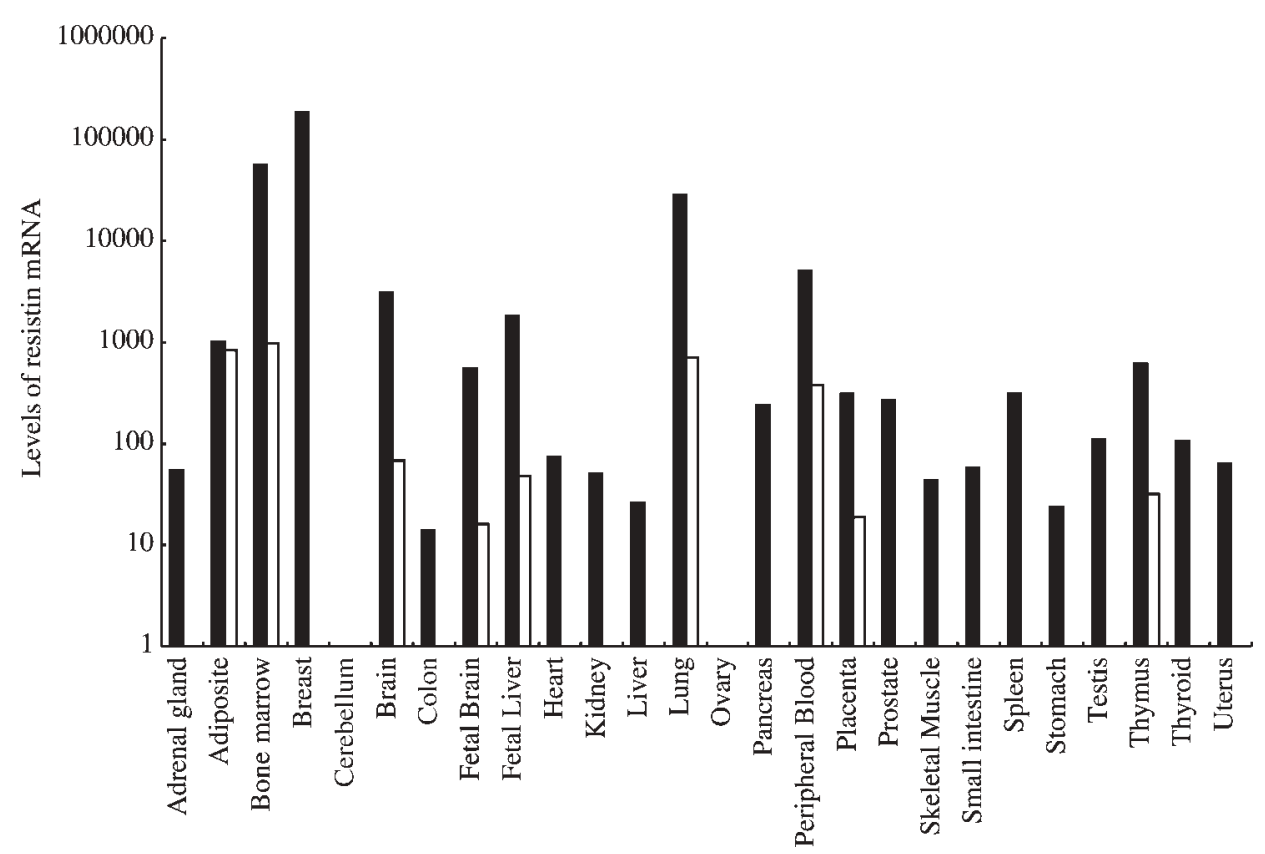

Figure 3 Full-length isoform of $h$ Resistin mRNA and $h$ Resistin delta2 mRNA in human tissues. Filled bars, $h$ Resistin full-length mRNA; open bars, $h$ Resistin delta2 mRNA. RT-PCR analyses were performed as described in Materials and methods. As normalization to the GAPDH housekeeping gene is inaccurate, mRNA expression levels are presented as the mRNA copy number per $\mu \mathrm{g}$ total RNA. These detection systems have a sensitivity of about 200 copies/ $\mu$ g total RNA. 
It might be expected, through its influence on resistin activity level, that ASV expression could influence clinical outcomes following molecular target therapy for resistin regulation. Further prospective studies will be required to uncover resistin delta2 ASV expression that regulates the expression of the resistin gene involved in endocrine networks for adipogenesis and adipocyte metabolism. Our results provide a basis for more detailed studies on the regulation of resistin activity, and should assist in the development of clinical trials with resistin for the central regulation of obesity and type 2 diabetes.

\section{Acknowledgements}

We thank Kimio Nishitani (SRL, Inc., Tokyo, Japan) and Go Ono (SRL, Inc., Kanagawa, Japan) for their secretarial assistance.

The sequence reported in this paper has been deposited in the GenBank database (accession no. AB111910).

\section{References}

1 Banerjee RR \& Lazar MA. Dimerization of resistin and resistin-like molecules is determined by a single cysteine. Journal of Biological Chemistry 2001276 25970-25973.

2 Bing C, Gomez-Ambrosi J, Zabalegui N, Williams G \& Trayhurn P. Resistin and RELM-alpha gene expression in white adipose tissue of lactating mice. Biochemical and Biophysical Research Communications $2002296458-462$.

3 Yang RZ, Huang Q, Xu A, McLenithan JC, Eison JA, Shuldiner AR et al. Comparative studies of resistin expression and phylogenomics in human and mouse. Biochemical and Biophysical Research Communications $2003310927-935$.

4 Steppan CM, Bailey ST, Bhat S, Brown EJ, Banerjee RR, Wright $\mathrm{CM}$ et al. The hormone resistin links obesity to diabetes. Nature $2001409307-312$

5 Shojima N, Sakoda H, Ogihara T, Fujishiro M, Katagiri H, Anai M et al. Humoral regulation of resistin expression in 3T3-L1 and mouse adipose cells. Diabetes 200251 1737-1744.

6 Savage DB, Sewter CP, Klenk ES, Segal DG, Vidal-Puig A, Considine RV et al. Resistin/Fizz3 expression in regulation obesity and peroxisome proliferator-activated receptor-gamma action in humans. Diabetes $2001502199-2202$.

7 McTernan PG, McTernan CL, Chetty R, Jenner K, Fisher FM, Lauer $\mathrm{MN}$ et al. Increased resistin gene and protein expression in human abdominal adipose tissue. Journal of Clinical Endocrinology and Metabolism 2002872407.

8 Morash BA, Willkinson D, Ur E \& Wilkinson M. Resistin expression and regulation in mouse pituitary. FEBS Letters $200252626-30$.

9 Delhanty PJ, Mesotten D, McDougall F \& Baxter RC. Growth hormone rapidly induces resistin gene expression in white adipose tissue of spontaneous dwarf (SDR) rats. Endocrinology 2002 $1432445-2448$.

10 Yura S, Sagawa N, Itoh H, Kakui K, Nuamah MA, Korita D et al. Resistin is expressed in the human placenta. Journal of Clinical Endocrinology and Metabolism $2003 \mathbf{8 8} 1394-1397$.

11 Sentinelli F, Romeo S, Arca M, Filippi E, Leonetti F, Banchieri M et al. Human resistin gene, obesity, and type 2 diabetes: mutation analysis and population study. Diabetes 200251 860-862.

12 Patel L, Buckels AC, Kinghorn IJ, Murdock PR, Holbrook JD, Plumpton $\mathrm{C}$ et al. Resistin is expressed in human macrophages and directly regulated by PPAR $\gamma$ activators. Biochemical and Biophysical Research Communications 2003300 472-476.

13 Li Y, Totsune K, Takeda K, Furuyama K, Shibahara S \& Takahashi K. Differential expression of adrenomedullin and resistin in 3T3L1 adipocytes treated with tumor necrosis factor-alpha. European Journal of Endocrinology 2003149 231-238.

14 Yuzuriha H, Inui A, Goto K, Asakawa A, Fujimiya M \& Kasuga M. Intracerebroventricular administration of NPY stimulates resistin gene expression in mice. International Journal of Molecular Medicine $200311675-676$.

15 Hisatomi H, Tanemura H, Iizuka T, Katsumata K, Nagao K, Sumida H et al. Differential alternative splicing expressions of thymidylate synthase isoforms. Cancer Letters $2003193127-131$.

16 Hisatomi H, Ohyashiki K, Ohyashiki JH, Nagao K, Kanamaru T, Hirata $\mathrm{H}$ et al. Expression profile of a gamma-deletion variant of the human telomerase reverse transcriptase gene. Neoplasia 20035 193-197.

17 Hisatomi H, Kohno N, Wakita K, Nagao K, Hirata H, Hikiji K et al. A novel alternatively spliced variant with a deletion of $52 \mathrm{bp}$ in exon 6 of the progesterone receptor gene is frequently observed in breast cancer. International Journal of Cancer $2003 \mathbf{1 0 5}$ $182-185$.

18 Hanke J, Brett D, Zastrow I, Aydin A, Delbruck S, Lehmann G et al. Alternative splicing of human genes more the rule than the exception. Trends in Genetics 199915 389-390.

19 Mironov AA, Fickett JW \& Gelfland MS. Frequent alternative splicing of human genes. Genome Research 1999 9 1288-1293.

20 Stallings-Mann ML, Ludwiczak RL, Klinger KW \& Rottman F. Alternative splicing of exon 3 of the human growth hormone receptor is the result of an unusual genetic polymorphism. PNAS 199693 12394-12399.

21 Liu W, Qian C \& Francke U. Silent mutation induces exon skipping of fibrillin-1 gene in Marfan syndrome. Nature Genetics 199716 $328-329$

22 Frischmeyer PA \& Dietz HC. Nonsense-mediated mRNA decay in health and disease. Human Molecular Genetics $1999 \mathbf{8}$ 1893-1900.

23 Lykke-Andersen J, Shu MD \& Steitz JA. Human Upf proteins target an mRNA for nonsense-mediated decay when bound downstream of a termination codon. Cell $2000 \mathbf{1 0 3} 1121-1131$.

24 Ukkola O. Resistin - a mediator of obesity-associated insulin resistance or an innocent bystander? European Journal of Endocrinology $2002147571-574$.

25 Banerjee RR \& Lazar MA. Resistin: molecular history and prognosis. Journal of Molecular Medicine $2003 \mathbf{8 1} 218-226$.

Received 13 January 2004

Accepted 26 April 2004 